\title{
Histological and Histochemical Investigations on the Stomachs in Man, Japanese Monkey (Macaca fuscata yakui) and Some Other Kinds of Animals
}

\author{
Report I. Cell-divisions in the Gastric Glands in Man, \\ Japanese Monkey and Dog
}

By

\author{
Masatake Imai, Taizo Shibata and Takao Mineda \\ Department of Anatomy, School of Dentistry, Aichi-Gakuin University \\ Chikusa-Ku, Nagoya, Japan
}

The mitoses in the parietal cells in man were recognized by B öhm-David of $f$ (1895), N a u werk (1897), P o p of $f$ (1897), A scoli (1901), Lim (1922), Z immermann (1925) and Plenk (1931). Tortora (1899), Cade $(1900,1901)$, Malesani (1909), K irk (1910), Harms (1910), and Debernardi (1912) also described the above mentioned cell-divisions in animals. On the other hand, however, Harvey (1907) and Ulkan (1912) denied the mitoses in the same cells. O h i s hi (1947) said that the parietal cells proliferated mainly through the amitoses in man, and $\mathrm{Sunohara}$ (1955) has reached the similar conclusion in man and rat. The mitoses in these cells were rarely recognized by $\mathrm{Ohishi}$, but $\mathrm{S}$ u nohara did not observe such division. Bizzozero (1893), Sa l o m on (1893), B e n s le y (1898), C a d e (1901), L i e ber t (1904), H a r ve y (1907), Lim (1922), Z i mmermann (1925), O hishi (1947) and $\mathrm{S} \mathrm{u}$ nohara (1955) denied the mitoses in the chief cells and they, including M a x mow-B loo m (1958) and Tokari (1960), excepting $\mathrm{S} u \mathrm{n}$ ohara, considered that the same cells were able to originate in the mucous neck cells. K id a (1938), however, denied this opinion. $\mathrm{Oh}$ ishi said that she recognized the transformation between the mucous neck cells and the chief cells, but could not affirm the transforming direction in them. According to the results basing upon the isolated preparations, $\mathrm{S} \mathrm{un}$ o hara described that the division in the chief cells were due to the amitoses and $\mathrm{O} h$ is h i rarely recognized the same cell-divisions in the sections. While, Salvi oli 
(1890), B izzozero (1893), B öh m-Da vidoff (1895), M a lesa n i (1909), $\mathrm{K} \mathrm{ir} \mathrm{k} \mathrm{(1910)} \mathrm{and} \mathrm{H}$ a r m s (1910) described the mitoses in the chief cells, but all of their opinions, except $\mathrm{K}$ irk's, have not been believed because of their misjudgments on their researches. Some investigators, such as Bensle y (1898), Cade (1901), Liebert (1904), Harvey (1907), Lim (1922), Z i m m e r man n (1925), Su noh ara (1955), Stöhr (1959) recognized the mitoses in the mucous neck cells. Ohishi (1947) and Tokari (1960) said that mitoses in the same cells were rarely found, and the former considered that those cells proliferated mainly through the amitoses. Is h i$\mathrm{z}$ a w a (1951), M aximow-B loom (1958) and B loom-Fawcett (1962) denied the mitoses in the above mentioned cells and they, including Tokari, considered that the new mucous neck cells were probably able to arise through a gradual transformation of the undifferentiated epithelium in the bottom of the foveolae and in the neck regions of the glands. S a c h s (1887), M e y e r (1889), E w a l d (1893), B o a s (1894), H a y e m (1894), S chmidt (1895), P o p of f (1897), L u barsch (1897), Le uk (1899), Letulle (1900), Einhorn (1902), B o eckelmann (1902), Harvey (1907), H e y row s y (1913), Stoerck (1922), Pasch k s-Orator (1923), O s h i a wa (1923), Borst (1923), Moszkowicz (1924), La uche (1924), Konjetzny (1928), Lehner (1928), Hamperl (1928) and Ishi$\mathrm{z}$ a w a (1951) described that it was possible that the mucous neck cells might arise through a transformation of the chief cells. We, the present authors, denied this opinion, basing upon their data of the histochemical investigations on the fundic glands in the Japanese monkeys (1965). After that, they have made a thorough investigations on the cell-divisions in the parietal, chief and mucous neck cells to affirm the origin and the replenishment of those cells and they will inform on the result in this report.

\section{Materials and Methods}

Two puppies, aged one month and three months, four adult dogs, four Japanese monkey (Macaca fuscata yakui) and seven human stomachs were used for the present study. The animals were killed by a rapid intravenous injection of Nembutal, and the human materials were obtained from the normal part of the resected cancerous or ulcerous stomachs. The materials were taken in as fresh a state as possible from the fundus, lesser and greater curvature regions. The tissues were fixed in buffered formalin, embedded in paraffin and 
cut in $4-6 \mu$ thin sections. The sections were stained with hematoxylin (Harris)-eosin, Heidenhain's iron hematoxylin, PAS reaction and $41 \times 10^{-4}$ toluidine blue solution. The nuclei in the mitoses are stained dark blue or greenish blue by the last described solution, due to the increase of quantity of DNA. While the resting nuclei are lightly stained. So, it is convenient to find the mitoses in the section preparations. The above described color characteristics in the mitoses cannot be recognized in the amitoses. We have made a thorough investigation in the presence of the mitoses and amitoses in the parietal, chief and mucous neck cells, but have not treated statistically.

\section{Observations}

1. Parietal cells (Figs. 1-6)

The mitoses in the parietal cells are rarely found in the adult dogs, monkeys and men. But they are not so rare in the one-monthand three-month-old puppies. The amitoses in the same cells are generally observed in the above described materials. As the nuclear divisions in the parietal cells are not always followed by the division of the cell bodies, we can recognize many polynuclear parietal cells in the section preparations. We do not meet a form of dumb-bell in the nucleus or cell body in the processes of the amitoses, and two daughter nuclei are connected with slender caryoplasm. There is a straight devision line between two daughter cells but such a line is not observed in the cell whose daughter nuclei keep too close. The division in the cell body begins in one side and reaches the other. This division line is PAS-positive, so we can clearly recognize the process of division in the section preparation.

2. Chief cells (Figs. 7-10)

The mitoses in the chief cells are frequently observed in the one-month-old puppy, while they are fewer in the three-month-old puppy as well as in the adult dogs, monkeys and men. And yet we have not difficulty in finding them out. Namely, we observed such cell divisions in each three out of the four dogs and the four monkeys and two out of the seven men. It is to be noted especially that we could find the mitoses in the stomachs of the two Japanese monkeys which were filled up with feed, and that we could also recognized a few mitoses in one out of the two monkeys which were killed about thirty seven hours after meal. Although, we often recognize the mitoses in the so-called immature chief cells (Figs. 11, 12, 15), we can 
find them sometimes also in the chief cells in the bottom of the glandular tubules. The so-called immature chief cells are distributed in the body parts of the glands and we consider that they are the remains in the processes of embryogenesis and they also originate in the mucous neck cells. Regarding this fact, we will inform in another report. By the way, many two-nuclear chief cells were found in any section with or without mitoses regardlessly.

3. Mucous neck cells (Figs. 11, 13-16)

We can easily find the mitoses in the mucous neck cells in the adult dogs, monkeys and men, even if the same cell-divisions are not observed in the chief cells in the same sections.

\section{Discussion}

\section{Parietal cells}

B ö h m-D a vid of $f$ (1895), N a u w e r k (1897), P o p of $f$ (1897), A scoli (1901), Lim (1922), Z immermann (1925) and Plenk (1931) recognized the mitoses in the parietal cells in man. Tortor a (1899), C a d e (1900, 1901), Malesani (1909), K irk (1910), Harms (1910) and Debernardi (1912) described the same cell-divisions in animals. While, Harvey (1907) and Ulkan (1912) denied it. O h is hi (1947) considered that the cell-divisions in the parietal cells in man mainly arised through the amitoses, and $\mathrm{Sunohara}$ also maintained similar opinion in man and rat. According to the researches on the dog, Japanese monkey and man, we, the present authors, approved of the opinions of $\mathrm{Oh}$ is hi and $\mathrm{Sunohara.} \mathrm{We}$ have difficulty in finding out the mitoses in the same cells even in the one-month-old puppy, while the same cell-divisions are easily observed in the chief cells in the same sections. Su nohara could not find the mitoses in the parietal cells in man and rat, while, be rare as it may, we found those in the dog, Japanese monkey and man, and $\mathrm{O} h \mathrm{i} \mathrm{s} \mathrm{h} \mathrm{i}$ also recognized similar division in man. We frequently found the nuclear divisions in the parietal cells but these divisions did not always follow those of the cell bodies. So we very often meet with the polynuclear cells in the same cells. The multiplication of those cells depends on the above mentioned cell-division, moreover, they are supplied from the undifferentiated cells which are distributed in the neck region of the glands. On this fact, we will make a detailed explanation in the following report. 


\section{Chief cells}

Salvioli (1890), Bizzozero (1893), Böhm-Davidoff (1895), Ma lesani (1909), Kirk (1910) and $\mathrm{H}$ a r m s (1910) described the mitoses in the chief cells, but excepting $\mathrm{K}$ i r k's opinion, the others' are not believed for their misjudgment on the difference between the mucous neck cells and the chief cells. On the other hand, Bizzozero. (1893), Salom on (1893), B e n sle y (1898), C a d e (1901), Li ebert (1904), Harve y (1907), Li m (1922), Z i m me r m a n (1925), Ohishi (1947) and Sunohara (1955) denied that division type. Moreover, they, including $\mathrm{Maximow}-\mathrm{Bl}$ oom (1958) and Tok a r i (1960), excepting $\mathrm{S} u \mathrm{n}$ o ha $\mathrm{r}$ a, consider that those cells can possibly arise through the transformation of the mucous neck cells, but this opinion was denied by $\mathrm{K}$ id a (1938). O h is hi recognized the transformation between the mucous neck cells and the chief cells, but she said that it was impossible to affirm the transforming directions in them. Sun o har a maintained that the divisions in the chief cells arise through the amitoses. We, the present authors, frequently observed the mitoses in the chief cells in the one-monthold puppy, and they didn't have difficulty in finding out the same celldivisions in the three-month-old puppy, adult dogs, Japanese monkeys and men, especially in their immature chief cells. Namely, we recognized considerable mitoses in each three out of the four adult dogs and two out of the seven men. But basing upon the fact that there are many two-nuclear chief cells in the section preparations, and upon the result of $\mathrm{S} u \mathrm{n}$ oh a $\mathrm{r}$ a which was made on the isolated preparations, we consider that those cells can divide into high frequency through the amitoses, and on this occasion, the amitotic proliferations in the chief cells seem to be principal. It is true that we cannot observe any mitotic division in the chief cells in some dogs, Japanese monkeys and men, but we interpret that the materials or sections we investigated happened to be those of nondividing period. After all, we obtained the undeniable fact that there were some more or less mitoses in the chief cells in man and animal.

In addition to the above mentioned cell multiplication, the chief cells are supplied from the immature chief cells which are the remains in the processes of embryogenesis and they also arise from the mucous neck cells and transform into the chief cells. We will report on this fact in detail on another opportunity (Report II). 


\section{Mucous neck cells}

Bensley (1898), Ca de (1901), Liebert (1904), H a r vey (1907), Li m (1922), Z i m m e rmann (1925), Sunohara (1955) and $\mathrm{Stöhr}$ (1959) recognized the mitoses in the mucous neck cells. $\mathrm{S} u \mathrm{n}$ o har a found out only the same cell-divisions in man and rat, and could not find the amitoses in those cells in the isolated preparations. O h i s h i (1947) rarely recognized such cell-divisions and emphasised that the proliferation of those cells depended on the amitoses. I s h i z a w a (1951), M a x i mow-B loom (1958) and B loom-F aw cet t (1962) denied the mitoses in those cells, and they, including Toka $\mathrm{ri}$ (1960), considered that the new mucous neck cells were probably able to arise through a gradual transformation of the undifferentiated epithelium in the bottom of the foveolae and in the neck region of the glands. M i y a k and $\mathrm{Kak} \mathrm{u}$ (1963) found out the generation zone in the neck region of the glands by means of ${ }^{3} \mathrm{H}$-thymidine radioautograph and they recognized that the generative cells were able to transform into the mucous neck cells. On the other hand, S a ch s (1887), M e ye r (1889), Ewald (1893), B o as (1894), H a y e m (1894), Schmidt (1895), Popoff (1897), Lubarsch (1897), Le u k (1899), L e tul le (1900), E in hor n (1902), B o e c k e l ma n n (1902), Harvey (1907), Hey r ow sky (1913), Stoerck (1922), PaschkisOrator (1923), Os hikaw (1923), Borst (1923), M os z k ow i c z (1924), La uche (1924), Konjetzny (1928), Lehner (1928), $\mathrm{H}$ a $\mathrm{m}$ pe r l (1928), O h is h i (1947) and Is h i z a w a (1951) considered that the mucous neck cells might arise through a transformation of the chief cells.* We, the present authors, frequently found out the mitoses in the mucous neck cells in the adult dogs, Japanese monkeys and men, even the above mentioned divisions were not recognized or were very rare in the chief cells in the same section preparation. We have no firm foundation for denying the amitoses in the mucous neck cells, but basing upon our result and $\mathrm{S} u \mathrm{n}$ o h a $\mathrm{r}$ a's research, we also consider that the proliferation in those cells are mainly dependent upon the mitoses. La d man (cite from B loom-Faw cett, 1962) considers by means of ${ }^{3} \mathrm{H}$-thymidine radioautograph that the principal site of mitoses exists in the neck regions of the gastric glands. And then we deny the above mentioned opinion* on the foundation of their present research and the histochemical differences between the mucous neck cells and the chief cells which will be subsequently reported. Moreover, the mucous neck cells aries from the undifferentiated cells which are mixed in them. 


\section{Summary}

After the observations on the cell-divisions in the gastric glands in two puppies, each four adult dogs and Japanese monkeys and seven men, the authors have obtained the following results.

1. The parietal cells proliferate mainly through the amitoses, moreover, be rare as it may, we can also find out the mitoses.

2. It is true that the amitoses take the lead in the proliferation in the chief cells and that most of the investigators deny the mitoses in those cells, but we have no difficulty in finding out the mitoses in the same cells in the adult dogs, Japanese monkeys and men.

3. The proliferations of the mucous neck cells are dependent upon the mitoses in the cells of the same kind, and the present authors deny the opinion which maintain the arising of those cells through a transformation of the chief cells.

4. The parietal, chief and mucous neck cells are also replenished by the transformation of the undifferentiated cells in the neck region of the glands. We will inform those facts in detail in other reports.

\section{Acknowledgement}

The authors heartily appreciate the kindness of Dr. Y. I y o masa, School of Medicine, Nagoya University, who offered to us the human stomachs.

\section{References}

Ascoli, C. Il mecanismo di formazione della mucosa gastrica umana. Arch. Sci. med., 25 : 257-295, 1901. (cite from Ple n k)

Bailey, F.R. and Copenhaver, W.M. Bailey's textbook of histology: 370-382, 1964.

Bensley, R. R. The structure of the mammalian gastric glands. Quart. J. microsc. Sci. Lond., N.s., 41 : 361-398, 1898. (cite from Ple n k)

B i z z o zero, G. Über die schlauchförmigen Drüsen des Magendarmkanals und die Beziehungen ihres Eepithels $z u$ dem Oberflächenepithel der Schleimhaut. Arch. mikrosk. Anat., 42: 82-152, 1893. (cite from Ple n k)

B loom, W. and F a w cet t, D.W. A textbook of histology: 431-442, 1962.

B o as, G. Diagnostik und Therapie der Magenkrankheiten, 1894. (cite from Ohishi)

$\mathrm{B}$ oe $\mathrm{ckel} \mathrm{mann}$ W. A. Untersuchungen zur pathologischen Anatomie des menschlichen Magens in Fällen von Ulcus und Carcinoma bei bekannter chemischer und motorischer Funktion. Z. klin. Med., $44: 128,1902$. (cite rom Ple n k)

Böh m, A. A. and D a vid of f, M. v. Lehrb. d. Menschen, 1895. (cite from Ple n k)

Borst. Pathologische Histologie, 1923. (cite from Ple n k)

$\mathrm{Cade}$, M. A. Modifications de la muqueuse gastrique an voisinage du nouveau pylore 
dans la gastroentéroanastomose expérimentale. Bibliogr. anat., $8: 242-260,1900$. (cite from Plenk)

$\mathrm{C}$ a d e, M. A. Etude de la constitution histologique normale et de quelques variations fonctionelles et expérimentales des éléments sécréteurs des glandes gastriques du fond chez les mammifères. Archives Anat. microsc., $4: 1-86,1901$. (cite from Ple n k)

Debernardi, G. Über die Regeneration der Schleimhaut des Magengrundes. Zbl. Path.,23 : 33, 1912. (cite from Plen k)

Einhorn, M. A further contribution to our knowledge of the histology of the gastric mucosa in pathological conditions of this organ. Amer. J. microsc. Sci., 124: 571-589, 1902. (cite from P l e n k)

E wa ld, C. A. Klinik der Verdauungskrankheiten, Bd. 2, 1893. (cite from Plenk)

$\mathrm{Hamperl}$. H. Über erworbene Heterotopien ortsfremden Epithels im Magendarmtrakt. Beitr. path. Anat., $80: 307-335,1928$. (cite from Ple n k)

Harms, W. Über der Haupt-und Belegzellen im Magen der Maus. Anat. H., 41 : 391-399, 1910. (cite from Plen k)

$\mathrm{H}$ a rvey, B.C.H. A study of the structure of the gastric glands of the dog and of the changes which they undergo after gastroenterstomy and occlusion of the pylorus. Amer. J. Anat., 6: 207-243, 1907.

H a y e m, G. Gastritis parenchymatosa. Allg. Wien. med. Ztg., $2: 17$ : 1894. (cite from Plenk)

$\mathrm{Hey} \mathrm{rowsky,} \mathrm{H.} \mathrm{Histologische} \mathrm{Untersuchungen} \mathrm{der} \mathrm{Magenschleimhaut} \mathrm{bei} \mathrm{Ulcus}$ ventriculi und Carcinom. Dtsch. Z. Chir., 122: 359-392, 1913. (cite from P1enk)

I s h i $z$ a w a, M. Manual of histology, Vol. II : 232-252, 1951. (in Japanese)

$\mathrm{Kida}$, Y. Cytological studies on the gastric mucosa in man, II. On the chief cells in the fundic glands. Osaka Ig. Z., $37: 1199,1938$. (cite from $\mathrm{O}$ h i s h i)

Kirk, E. G. On the histogenesis of gastric glands. Amer. J. Anat., $10: 473-520,1910$. (cite from Plenk)

Konjetzny. Die Entzündungen des Magens. Henke-Lubarschs. Handb. d. spez. path. Anat., 4, 1928. (cite from Ple n k)

$\mathrm{L}$ a u che, A. Die Heterotopien des ortsgehörigen Epithels im Bereiche des Verdauungskanals. Virchows Arch., 252: 39-88, 1924. (cite from Plen k)

Lehner, J. Zur Bemerkung und Charakterisierung der Magendrüsen Wien. klin. Wschr., $41: 702,1928$. (cite from $\mathrm{Oh}$ ish i)

L e tulle, M. Anatomie pathologique générale des lesions inflammatoires. Bouchard, Pathologie general, 3 II : 553-642, 1900. (cite from P le n k)

$\mathrm{L}$ e u k. Untersuchungen zur pathologischen Anatomie des menschlichen Magens mit Ber ücksichtigung der praktischen Verwertbarkeit anatomisch diagnostizierter Magenschleimhautstückchen. Z. klin. Med., 37: 296, 1899. (cite from Ple n k)

$\mathrm{L}$ i e be rt, A. Über die Fundusdrüsen des Magens beim Rhesusaffen. Arb. anat. Inst., 23 : 495-540, 1904. (cite from Plen k)

L i m, R. K.S. The gastric mucosa. Quart. J. microsc. Sci., $66: 187-212$, 1922. (cite from Plenk)

L i son, L. Histochimie et cytochimie animales, principes et methodes: 263, 1962. (in Japanese)

Lubarsch, O. Anatomischer Beitrag zu: F. Martins, Achylia gastrica, 1897. (cite from Plenk)

Malesani, A. Contributo allo studio della rigenerazione delle mucosa gastrica. Arch. ital. Anat., 8 : 359-374, 1909. (cite from Ple n k)

Maximow, A.A. and Bloom, W. A textbook of histology: 375-384, 1958.

M e y e r, G. Zur Kenntnis der sog. „, Magenatrophie”. Z. klin. Med., 16: 366, 1889. 
(cite from $\mathrm{Oh}$ is hi)

$\mathrm{Mi}$ a ke, K., Kaku, H., Kojima, A. and Fujita, S. Studies on the "generative cell" and its kinetics in the epiithelium of gastric mucosa by means of ${ }^{3} \mathrm{H}$ thymidine flash labeling autoradiography and electron microscope. Tr. Soc. Path. Jap., 52: 186, 1963. (in Japanese)

Moszkowicz, L. Regeneration und Krebsbildung an der Magenschleimhaut. (Grundlagen einer biologischen Krebstheorie.) Arch. Klin. Chir., 132: 558-620, 1924. (cite from Plen k)

$\mathrm{Na}$ u werck, C. Gastritis ulcerosa chronica. Ein Beitrag zur Kenntnis des Magengeschwürs. Münch. med. Wschr. 1897: 955-958, 987-990. (cite from Plenk)

$\mathrm{Oh}$ is hi, K. Cytological studies on the human gastric glands. I. Cytological studies on the chief cells. Diss., Tokyo Women's Med. Coll., 1-40, 1947. (in Japanese)

$\mathrm{Oh}$ is hi, K. Cytological studies on the human gastric glpnds. II. Cytological studies on the parietal cells. Diss., Tokyo Women's Med. Coll. 1-43, 1947. (in Japanese)

$\mathrm{O}$ hishi, K. Cytological studies on the human gastric glands. III. Cytological studies on the mucous neck cells. Diss., Tokyo Women's Med. Coll. 1-37, 1947. (in Japanese)

Oshikawa. Über die Magesnschleimhaut bei gastroenterostomierten Hunden mit besonderer Berücksichtigung der Bizzozeroschen Spirochätenbefunde. Arch. klin. Chir., 124 : 559-564, 1923. (cite from Plen k)

Paschkis, K. and Orator, V. Beitrag zur Normal histologie des menschlibhen Magens (Versuch einer Histotopographie). Z. Anat., 67: 494-516, 1923. (cite from Ple n k)

Plen k, H. Zur Entwicklung des menschlichen Magens. Z. mikrosk.-anat. Forschg., 26 : 547-645, 1931. (cite from Ple n k)

Plenk, H. Der Magen. Möllendorffs Handb. d. mikrosk. Anat. d. Menschen. V-2: 88-234, 1932.

P o p of f, P. M. Über Magenkatarrh. Z. Klin. Med., $32: 389,1897$. (cite from P le n k)

Sachs, A. Zur Kenntnis der Magenschleimhaut in Krankhaften Zuständen. Arch. f. exper. Path., $22: 155,1887$ (cite from Ohish i)

Salomon, H. Beiträge zur Anatomie des Magens der catarrhinen Affen (Cercopithecus und Inuus). Arch. mikrosk. Anat., 41:19-27, 1893. (cite from P le n k)

Salvioli, J. Quelqes observations sur le mode de formation et d'accroissement des glandes de l'estomac. Internat. Mschr. Anat. u. Physiol., 7: 396-413, 1890. (cite from $\mathrm{Ple} \mathrm{n} \mathrm{k}$ )

$\mathrm{Schmidt}$ A. Ein Fall von Magenschleimhautatrophie nebst Bemerkungen über sogenannte ,schleimige Degeneration der Drüsenzellen des Magens". Dtsch. med. Wschr., 21: 300, 1895. (cite from Oh is hi)

S t oe r c k, O. Über Gastritis chronica. Wien. Klin. Wschr., 855-860, 1922. (cite from Ple $\mathrm{nk}$ )

Stöhr/v. Möllendorff/Goerttler. Lehrbuch der Histologie und der mikroskopischen Anatomie des Menschen: 292-299, 1959.

Sunohara, Y. Study on the proliferation of gastric epithelia and glandular cells in the frog. Shinshu Igak. Z., 5: 19-29, 1956. (in Japanese)

Sunohara, Y. On the regenerative proliferation of the cells of the gastric surface epithelium and the gastric glands of the rat. Shinshu Igak. Z., 5: 86-91, 1956. (in Japanese)

Sunohara, Y. On the proliferation of epithelium of gastric mucosa and cells of gastric glands. Shinshyu Igak. Z., 5: 194-200, 1956. (in Japanese)

Tokari, C. Histology: 251-256, 1960. (in Japanese)

Tortora, C.J. Sulle cellule glandolari dello stomaco. Riforma med. Napoli, 15 : 
267-270, 1899. (cite from Ple n k)

U I k a n, G. Die Entwicklung der Fundusdrüsen im Magen des Schweines. Vorl. Mitt. Anat. Anz., 41 : 78-80, 1912. (cite from Ple n k)

Zimmermann, K. W. Beitrag zur Kenntnis des Baues und der Funktion der Fundusdrüsen im menschlichen Magen. Erg. Physiol., $24: 281-307,1925$. (cite from Ple n k)

\section{Plate I. \\ Explanation of figures}

Fig. 1. Mitosis in the parietal cell $(\uparrow)$ in man, stained with $41 \times 10^{-4}$ toluidine blue solution. $\times 1,000$

Fig, 2. Mitosis in the parietal cell $(\hat{\imath})$ in the Japanese monkey, stained with $0.05 \%$ toluidine blue solution at $\mathrm{pH} 2.5 . \times 1,000$.

Fig. 3. Mitosis in the parietal cell $(\uparrow)$ in the dog, stained with hematoxylin-eosin. $\times 550$.

Fig. 4. Amitosis in the parietal cell $(\uparrow)$ in man, but cytoplasmic division does not arise yet. Periodic acid-Schiff-hematoxylin. $\times 1,000$.

Fig. 5. Amitosis in the parietal cell in man. PAS-positive dividing line in the cytoplasm is partly seen $(\uparrow)$. Periodic acid-Schiff-hematoxylin. $\times 1,000$.

Fig. 6. Trinucleate parietal cell $(\uparrow)$ in man. Dividing line in the cytoplasm is not seen. Periodic acid-Schiff-hematoxylin. $\times 1,000$.

Fig. 7. Mitosis in the chief cell $(\uparrow)$ in man, stained with hematoxylin-eosin. $\times 550$.

Fig. 8. Mitosis in the chief cell $(\uparrow)$ in the Japanese monkey, stained with $25 \times 10^{-4}$ toluidine blue solution. $\times 1,000$.

\section{Plate II. \\ Explanation of figures}

Fig. 9. Mitosis in the chief cell $(\hat{\imath})$ in the dog, stained with $1 \%$ cresyl violet. $\times 1,000$.

Fig. 10. Mitosis in the chief cell $(\hat{\imath})$ in the dog, stained with hematoxylin-eosin. $\times 550$.

Fig. 11. Mitosis in the mucous neck cell (1) and the immature chief cell (2), and the chief cell (3) in the Japanese monkey, satined with $0.05 \%$ toluidine blue solution at $\mathrm{pH} 2.5$. $\times 330$.

Fig. 12. Mitosis in the immature chief cell $(\hat{\imath})$ in the dog, stained with $1 \%$ cresyl violet. $\times 1,000$.

Fig. 13. Mitosis in the mucous neck cell $(\uparrow)$ in man, stained with $0.05 \%$ toluidine blue solution at $\mathrm{pH} 2.5$. $\times 550$.

Fig. 14. Mitosis in the mucous neck cell $(\uparrow)$ in the Japanese monkey, stained with $0.05 \%$ toluidine blue solution at $\mathrm{pH} 2.5 . \times 550$.

Fig. 15. Mitosis in the mucous neck cell (1) and the immature chief cell (2) in the dog, stained with $0.05 \%$ toluidine blue solution at $\mathrm{pH} 4.1 . \times 1,000$.

Fig. 16. Mitosis in the mucous neck cell $(\uparrow)$ in the dog, stained with hematoxylineosin. $\times 550$. 
Plate I

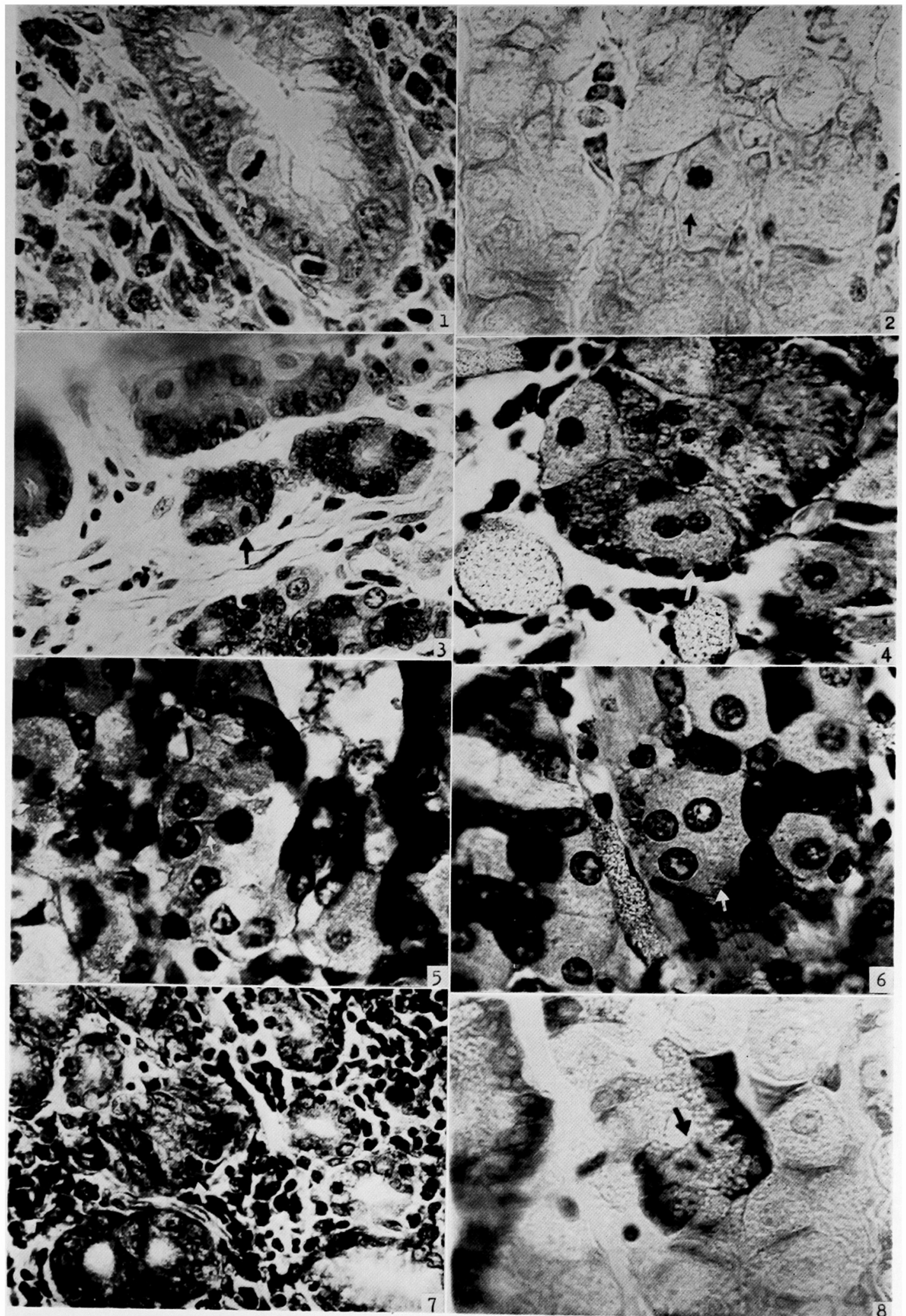

M. Imai, T. Shibata and T. Mineda. 
Plate II

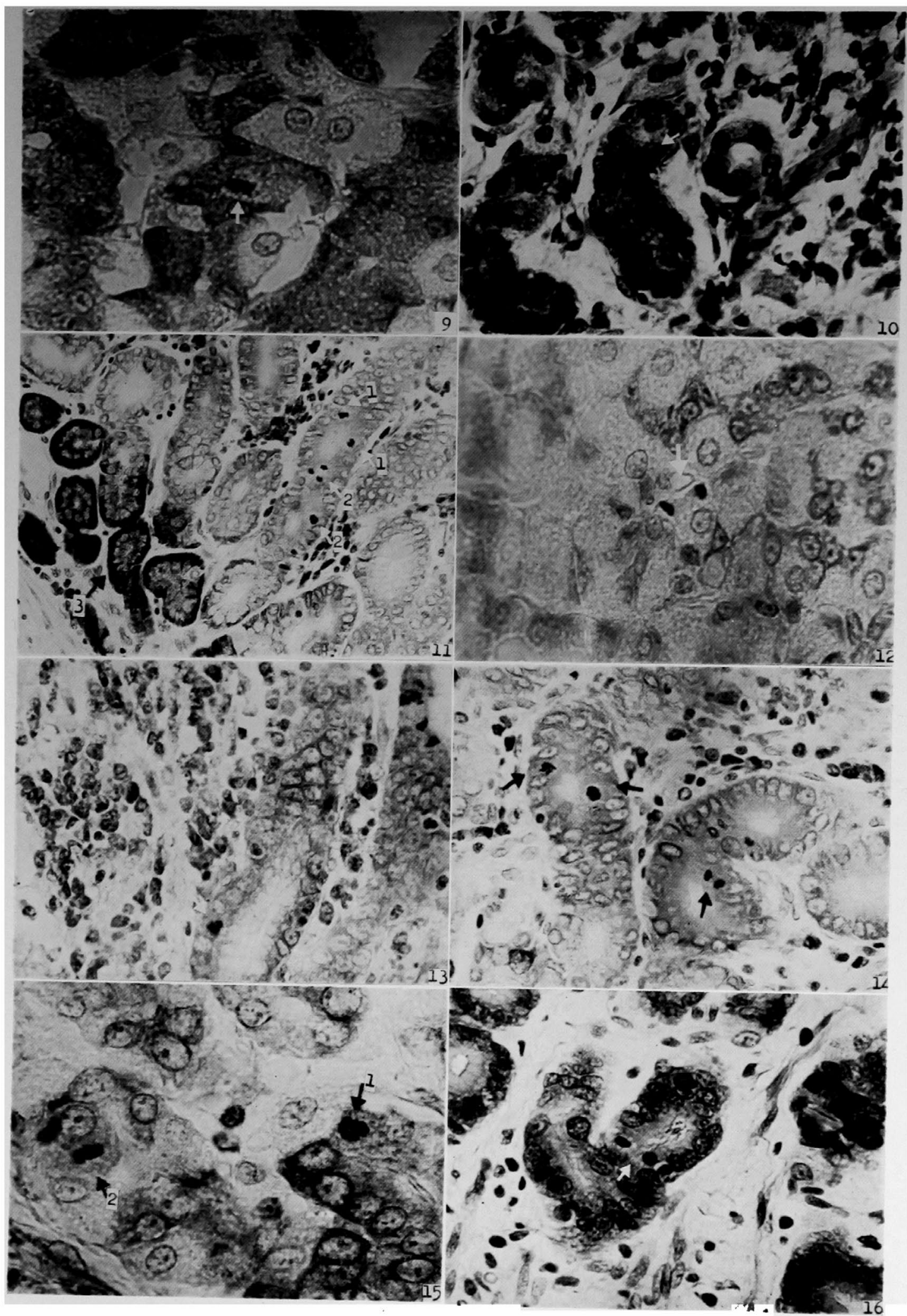

M. Imai, T. Shibata and T. Mineda. 